\title{
TAR OIL AS A NEW ALTERNATIVE FOR CONTROLLING THE TWO SPOTTED SPIDER MITE, TETRANYCHUS URTICAE (KOCH) INFESTING SOYBEAN PLANTS
}

\author{
EL-SISI, A. G. ${ }^{1}$, MARIAM A. EL-SANADY ${ }^{2}$, H. A. AZOUZ ${ }^{2}$ and \\ MAHASEN A. ABD EL-AZIZ ${ }^{2}$ \\ 1. Central Agricultural Pesticides Laboratory, ARC, Dokki, Giza, Egypt \\ 2. Plant Protection Research Institute, ARC, Dokki, Giza, Egypt
}

(Manuscript received 23 January 2013)

\begin{abstract}
Tar oil was prepared as soluble liquid $95 \%$ and evaluated against the two spotted spider mite, Tetranychus urticae (Koch) infesting soybean plants (G/ycin max) in Beni Suef Governorate and its associated predacious mites at different concentrations $1,1.5$ and $2 \%$ (V./V.). Its acaricidal effect increased with increasing concentration and time after application up to 12 days. $2 \%$ concentration was suitable for controlling the two spotted spider mite, T. urticae with less effect against predacious mites.
\end{abstract}

\section{INTRODUCTION}

The two-spotted spider mite, Tetranychus urticae (Koch) is considered as one of the most economically important pest in Egypt infesting field crops, orchard trees, ornamentals, medical plants and vegetables crops. Chemical control of this pest with acaricides is the most effective mean but because of its high cost, risk to man, beneficial animals, and environmental pollution, therefore efforts should be directed towards finding new alternatives being more safe, and cheep for controlling different pests. In Egypt, many researches were conducted for controlling injurious mites with many alternatives related to: Mineral and plant oils (Iskander and El-Sisi, 2001), (Mousa and El-Sisi, 2001a). Surface active agents (Rizk et. al., 1999, El-Sisi et. al., 2006). Mineral salts (Mousa and El-Sisi, 2001b) and foliar fertilizers (El-Sisi and Mousa, 2001).

Tar oil used in this study acts $50 \%$ waste distillation of charcoal manufacture, is considered a new alternative compound, which proved acaricidal effect against the stored grain mite, Tyrophagous putrescentige (Shrank) (El-Sanady and El-Sisi, 2011) when prepared as dustable powder, also against bollworm (Amer and El-Sisi, 2011) when prepared as soluble liquid.

The aim of this work was to investigate the acaricidal efficacy of tar oil locally prepared as soluble liquid against the spider mite, T. urticae (Koch) infested soybean plants and its side effect on dominate associated predacious mites and other pests. 


\section{MATERIALS AND METHODS}

\section{Crude tar oil}

Tar oil, a crude compound from the waste distillation of charcoal manufacture under $55^{\circ} \mathrm{C}$ in Egypt New \& Renewable Energy Authority (NREA), seven district, Nasr City, used as active ingredient in this study.

-Wetting and spreading agent:

600 m.I.: It is nonionic surfactant, brief name of polyethylene glycol 600 mon laurate.

\section{Methods}

\section{1- Preparation of tar oil as soluble liquid formulation:}

It was done by dissolving $5 \mathrm{ml}$ of spreading agent $600 \mathrm{~m} . \mathrm{l}$. in $95 \mathrm{ml}$ tar oil.

2-Field evaluation of the locally prepared tar oil $95 \%$ against $\boldsymbol{T}$. urticae infested soybean plants and its associated predacious mites:

This experiment was carried out in Beni Suef governorate in soybean field heavily infested with the two spotted spider mite $T$. urticae to evaluate the acaricidal efficacy of tar oil $95 \%$ SL and its side effect on the associated predacious mites. The experiment area was divided into four treatments, three of it for tar oil, at concentrations of $1,1.5$ and $2 \%$ (V./V.) and one for the control, and each treatment included three replicates. The replicates were distributed in a complete randomized block design. Spraying was done using a knapsack sprayer at July, 10, 2012. Sample was 10 leaves/each replicate and collected randomly before spraying and after 3, 6, 9, 12 and 15 days after spray. Alive spider mite and predatory mites were counted and percentages of reduction were calculated using Henderson and Tilton equation (1955). The data were subjected to analysis of variance (ANOVA) and the means were compared by L.S.D. test at 0.05 level, using SAS program (SAS, 1988). 


\section{RESULTS AND DISCUSSION}

Effect of tar oil $95 \%$ SL on population densities of the two spotted spider mite, T. urticae

Results in table (1) indicated that tar oil at concentrations 1, 1.5 and $2 \%$ decreased the mean alive number/10 leaves of moveable stages of $T$. urticae infested soybean plants in Beni Suef governorate compared with untreated. Also, the reduction percentages increased as well as increasing concentration of tar oil and, by increasing time after spraying up to 12 days of treatment.

Statistical analysis in table (1) showed highly significant differences between the application of tar oil at different concentrations 1, 1.5 and $2 \%$ comparing with untreated on the mean alive number/10 leaves of moveable stages of the spider mite, T. urticae ( $F=131.63$, L.S.D. $0.05=8.3)$.

Acaricidal efficacy of tar oil $95 \%$ SL against the two spotted spider mite, $T$. urticae infested soybean plants

Table (2) showed the acaricidal activity of tar oil expressed as reduction percentages of $T$. urticae on soybean plants calculated according to Henderson and Tilton equation (1955), indicated that it increased by increasing both concentration and time after application up to 12 days of application. The reduction percentages were $55.7,66.5$ and $79.6 \%$ after 12 days for the three increasing concentrations $1.0 \% 1.5 \%$ and $2 \%$ respectively. However percentage began to decrease after two weeks averaging $39.9 \%, 54.9 \%$ and $66.1 \%$ for the same concentrations respectively.

Side effect of tar oil $\mathbf{9 5 \%}$ SL on predacious mites associated with the two spotted spider mite $T$. uricae infesting soybean plants

The predacious mites collected in this study were: Agistemus exertus Gonzalez (Family : Stigmaeidae) and Phytoseiulus persimilis Athias-Henriot, Euseius scutalis H.-H. and Neoseiulus neoreticulatus Yousef \& El-Borollosy (Family : Phytoseiidae). Table (3) gave the number of predatory mites before and after application while its reduction percentages shown in table (4), indicated that the general mean reduction was $17.59 \%, 21.60 \%$ and $31.95 \%$ for tar oil at $1 \%, 1.5 \%$ and $2 \%$ respectively.

This study indicated that the predacious mites are more tolerant against tar oil than T. urticae.

It could be concluded that concentration $2 \%$ of tar oil was suitable for controlling the spider mite, $T$. urticae on soybean plants with less bad effect against predacious mites, as well as no phytotoxicity on treated plants. 
Statistical analysis in table (3) showed highly significant differences between the application of tar oil at concentrations $1,1.5$ and $2 \%$ compared with untreated on the mean alive number $/ 10$ leaves of predacious mites $(F=161.06$, L.S.D. $0.05=$ 1.51).

Results obtained well agreed with those of El-Sanady and El-Sisi, 2011 and Amer and El-Sisi, 2011. The toxic effects against spider mite might be due to its contents of phenols, creosote and anthracene (Tomlin, 1994).

It could be concluded that concentration $2 \%$ of tar oil was the suitable for controlling spider mite, $T$. urticae on soybean plants with less bad effects against predacious mites. 
Table. 1. Effect of tar oil $95 \%$ SL at different concentrations on population densities of the two spotted spider mite, Tetranychus urticae (Koch) on soybean plants in Beni-Suef governorate during summer season 2012.

\begin{tabular}{|c|c|c|c|c|c|c|c|c|}
\hline \multirow{2}{*}{ Treatment } & \multirow{2}{*}{$\begin{array}{c}\text { Conc.\% } \\
\text { (V./V.) }\end{array}$} & \multirow{2}{*}{$\begin{array}{c}\text { Mean alive } \\
\text { number/10 leaves } \\
\text { before treatment }\end{array}$} & \multicolumn{6}{|c|}{ Mean alive number/10 leaves after indicated days } \\
\hline & & & 3 & 6 & 9 & 12 & 15 & $\begin{array}{c}\text { Mean No./10 } \\
\text { leaves }\end{array}$ \\
\hline \multirow{3}{*}{ Tar oil } & 1.0 & 245.0 & 201.7 & 167.7 & 158.3 & 146.7 & 188.3 & 172.43 \\
\hline & 1.5 & 268.3 & 195.0 & 165.0 & 150.0 & 121.7 & 155.0 & 157.34 \\
\hline & 2.0 & 241.7 & 113.3 & 85.0 & 80.0 & 66.7 & 105.0 & 90.0 \\
\hline Untreated & - & 273.3 & 281.7 & 306.7 & 356.7 & 370.0 & 350.0 & 333.02 \\
\hline $\mathrm{F} 0.05$ & \multicolumn{7}{|c|}{-} & $131.63^{* * *}$ \\
\hline L.S.D. & & & & & & & & 8.3 \\
\hline
\end{tabular}

L.S.D. $=$ Least significant difference at 0.05

Table. 2. The reduction percentages of the two spotted spider mite, Tetranychus urticae (Koch) after application with tar oil on soybean plants in Beni Suef governorate.

\begin{tabular}{|c|c|c|c|c|c|c|c|}
\hline \multirow[b]{2}{*}{ Treatment } & \multirow{2}{*}{$\begin{array}{l}\text { Conc.\% } \\
\text { (V./V.) }\end{array}$} & \multicolumn{6}{|c|}{$\%$ reduction of moving stages after application } \\
\hline & & 3 days & 6 days & 9 days & 12 days & 15 days & $\begin{array}{c}\text { Average percent } \\
\text { reduction }\end{array}$ \\
\hline \multirow{3}{*}{ Tar oil } & 1.0 & 20.1 & 39.2 & 50.5 & 55.7 & 39.9 & 40.1 \\
\hline & 1.5 & 29.5 & 45.2 & 54.2 & 66.5 & 54.9 & 50.1 \\
\hline & 2.0 & 54.4 & 68.7 & 74.6 & 79.6 & 66.1 & 68.6 \\
\hline
\end{tabular}


Table. 3. Effect of tar oil $95 \%$ SL at different concentrations on associated predaceous mites on soybean plants in Beni-Suef governorate during summer season 2012.

\begin{tabular}{|c|c|c|c|c|c|c|c|c|}
\hline \multirow{2}{*}{ Treatment } & \multirow{2}{*}{$\begin{array}{c}\text { Conc. \% } \\
\text { (V./V.) }\end{array}$} & \multirow{2}{*}{$\begin{array}{c}\text { Mean alive } \\
\text { number } / 10 \text { leaves } \\
\text { before treatment }\end{array}$} & \multicolumn{6}{|c|}{ Mean alive numbers 10 leaves on indicated days of treatments } \\
\hline & & & 3 & 6 & 9 & 12 & 15 & $\begin{array}{c}\text { Mean No./10 } \\
\text { leaves }\end{array}$ \\
\hline \multirow{3}{*}{ Tar oil } & 1.0 & 51.67 & 43.33 & 46.67 & 63.67 & 80.33 & 100 & 66.80 \\
\hline & 1.5 & 43.33 & 40.00 & 38.67 & 47.33 & 63.33 & 91.67 & 56.20 \\
\hline & 2.0 & 51.67 & 41.00 & 43.00 & 53.00 & 64.00 & 85.00 & 57.20 \\
\hline Untreated & - & 55.00 & 61.67 & 74.00 & 83.33 & 98.33 & 130.00 & 89.47 \\
\hline $\mathrm{F} 0.05$ & \multicolumn{7}{|c|}{-} & $116.06 * * *$ \\
\hline L.S.D. & & & & & & & & 1.51 \\
\hline
\end{tabular}

L.S.D. = Least significant difference at 0.05

Table. 4. Reduction percentages of predacious mites populations after application of tar oil on soybean plants in Beni-Suef governorate during summer season 2012.

\begin{tabular}{|c|c|c|c|c|c|c|c|}
\hline \multirow[b]{2}{*}{ Treatment } & \multirow{2}{*}{$\begin{array}{l}\text { Conc. \% } \\
\text { (V./V.) }\end{array}$} & \multicolumn{6}{|c|}{ \%reduction of moving stages after application } \\
\hline & & 3 days & 6 days & 9 days & 12 days & 15 days & $\begin{array}{c}\text { Average percent } \\
\text { reduction }\end{array}$ \\
\hline \multirow{3}{*}{ Tar oil } & 1.0 & 25.21 & 12.90 & 18.67 & 13.04 & 18.12 & 17.59 \\
\hline & 1.5 & 17.67 & 33.67 & 27.90 & 18.25 & 10.49 & 21.60 \\
\hline & 2.0 & 29.23 & 38.15 & 32.30 & 30.72 & 30.40 & 31.95 \\
\hline
\end{tabular}

;IIIIm 


\section{REFERENCES}

1. Amer, R. A. M. and A. G. El-Sisi. 2011. Insecticidal activities of locally formulated tar oil as soluble liquid on the pink bollworm, Pectinophora gossypiela (Saunders). Egypt. J. Agric. Res., 89 (2): 445-461.

2. El-Sandy, Mariam A. and A. G. El-Sisi. 2011. Evlauation of tar oil formulated as dustable powder against grain mite, Tyrophagous putrescentiae (Sharnk). Egypt. J. of Appl. Sci., 25 (4B): 142-147.

3. El-Sisi, A. G. and Gehad, M. Mousa. 2001. Foliar fertilizers as important alternatives in controlling agricultural pests. Safe Alternatives of Pesticides For Pest Mangement. Assuit Univ., oct. 28-29th, p 71-81.

4. El-Sisi, A. G., A. F. Khattab, F. A. El-Essawy and R. M. Shawky. 2006. Preparation of some surface active agents and evaluation of its pesticidal efficacy against sucking pests infesting common bean. J. Agric. Sci. Mansoura Univ., 31 (10): 6713-6722.

5. Henderson, C. F. and E. W. Tilton. 1955. Test with acaricidal against the brown wheat mite. J. Econ. Entomol., 48: 157-161.

6. Iskander, Nadia, N. and A. G. El-Sisi (2001): Field evaluation of some local formulated plants and mineral oils against sucking pests infesting bean plants. J. Agric. Sci. Mansoura Univ., 26 (7): 4531-4535.

7. Mousa, G. M. and A. G. El-Sisi. 2001a. Testing of some alternatives: Mineral oil, plant materials and surfactant against piercing and sucking pests infested squash crop. Safe Alternatives Of Pesticides For Pest Mangement. Assuit Univ., Oct. 28-29th, p. 83-90.

8. Mousa, G. M. and A. G. El-Sisi. 2001b. Pesticidal efficiency of some inorganic salts against sucking pests infested Paseolous vulgaris (L.) seedling. Egypt. J. Agric. Res., 79 (3): 835-845.

9. Rizk, A. A., A. G. El-Sisi, N. A. Badr and S. M. Abdel Haleem. 1999. Controlling of cotton pests using safe materials. 2nd Int. Conf. of Pest Control, Mansoura, 211221.

10. SAS. 1988. SAS/STAT User`s Guide, Ver. 6.03. (SAS Institute Inc., Cary, North Carolina, $22 \mathrm{pp})$.

11. Tomlin, C. 1994. The pesticide Manual Incorporation The Agrochemical (handbook) (10th ed., The Royal Society of Chemistry, Crop Protection Publications, pp 1341. 


\section{الزيت القطراني كبديل جديا لمكافحة العنكبوت الأحمر ذي البقعتين الذي يصيب فول الصويا}

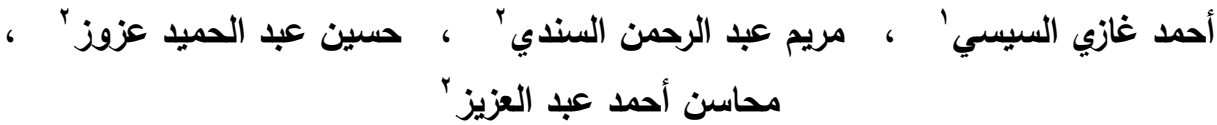

$$
\begin{aligned}
& \text { ا - المعدل المركزي للمبيد/ت - مركز البحوث الزراعية - الدقي - مصر } \\
& \text { r - معر بحوث وقاية النباتات - مركز البحوث الزراعية - الدقي - مصر }
\end{aligned}
$$

تم تحضير الزيت المعدني القطراني المجز علي صورة محلول قابل للذوبان 90\% ونم تقييمه ضد العنكبوت الأحمر ذي البقعتن الذي يصيب نباتات فول الصويا في محافظة بني سويف وتأثيره

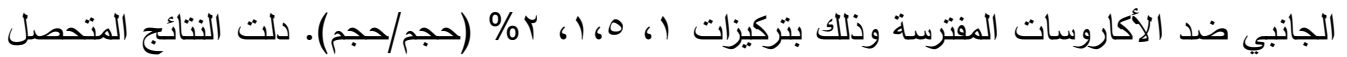
عليها علي أن نسبة الخفض في تعداد العنكبوت الأحمر تزداد بزيادة التركيز المستخدم كذلك بزيادة

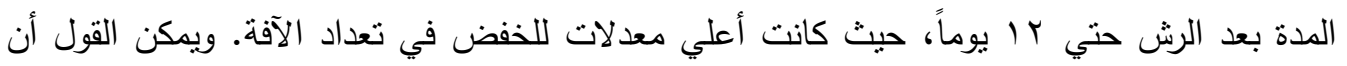

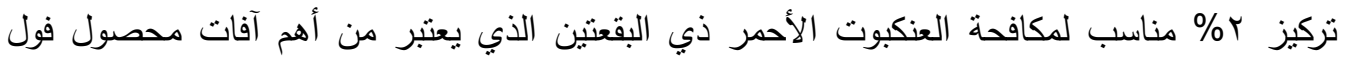
الصويا ويسبب خسائر جسيمة للمحصول مع وجود تأثنر جانبي قليل ضد الأكاروسات المفترسة.

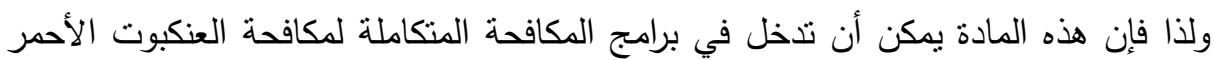
علي محصول فول الصويا بإعنباره من أهم الآفات التي تؤثر في إنتاجية المحصول كماد ولئ وكيفا. 